School of Finances of Law

Bielsko-Biała

The Vienna Institute for International Economic Studies

Vienna

\title{
FOOD DEMAND: EVIDENCE FROM INTERNATIONAL COMPARISON PROGRAM 2011 DATA
}

\begin{abstract}
Data for 41 European and OECD countries from the International Comparison Program for 2011 are used to estimate the AIDS demand system distinguishing two aggregates: food and all other goods and services ("non-food') included in individual consumption expenditure of households. The demand elasticities derived indicate that food is a 'normal good' in countries with p.c. volume of total individual consumption not exceeding ca. 17 thousand international dollars. In countries with higher levels of total consumption volumes food appears to be an 'inferior' good. Own-price elasticity of food demand is higher than-1.0: food demand is 'inelastic'. Additionally, estimates are presented of the elasticises of the relative price (food over 'non-food') with respect to the volumes of supplies offood and 'non-food'. These estimates indicate that in richer countries rising supplies of 'non-food' depresses the relative price of food. This is consistent with the 'price-scissors' tendency acting against the food and agriculture sector.
\end{abstract}

Keywords: International Comparison Program, Engel's Law, food demand, demand elasticities, AIDS, price scissors.

JEL codes: Q11, D12, O57. 


\section{Introduction}

International Comparison Programs (ICP) provide details on the actual levels of the gross domestic product (GDP) and its elements, including individual consumption expenditure by households. In addition, some sub-aggregates, for example food consumption, are distinguished under ICP. At the same time, ICP provides estimates for purchasing power parities (PPP) of national currencies in relation to whole GDP and its specified components. With its construction, ICP data allows for direct comparison of GDP (and its components) volumes per capita for different countries ${ }^{1}$.

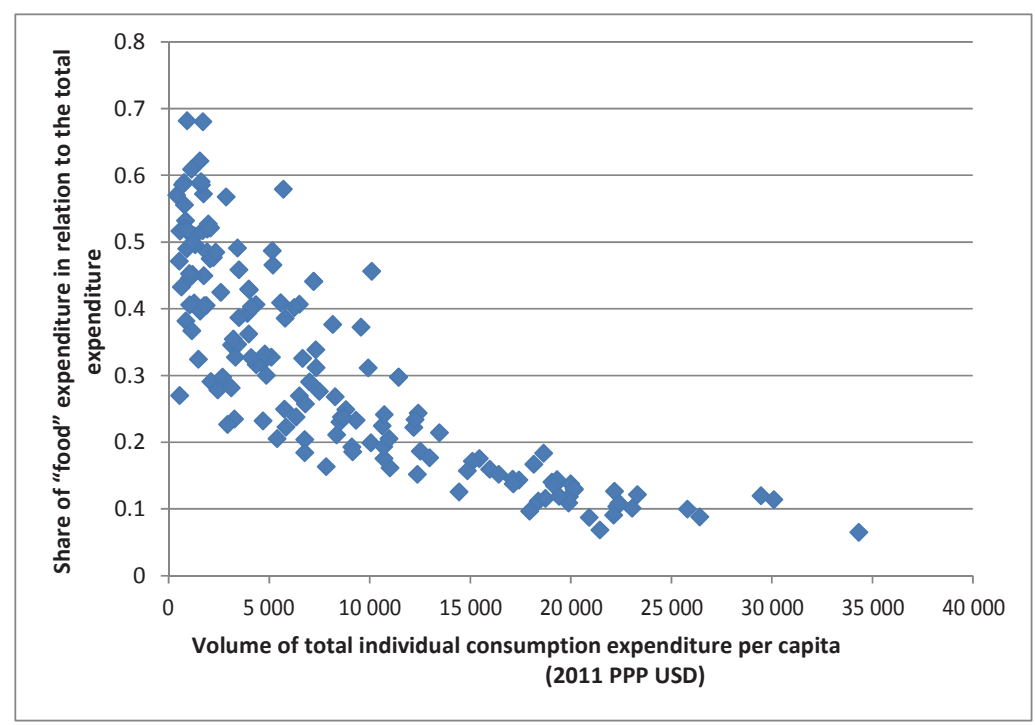

Fig. 1. Share of food expenditures according to the volume of total individual consumption expenditure per capita.

Note: The individual consumption expenditure volume is expressed in "international dollars" for 2011 measuring purchasing power of the national currency against the US dollar (i.e. 2011 PPP USD). Figure 1 provides 159 points for ICP 2011 countries (40 mini-countries and territories of Caribbean and Oceania regions were omitted, similarly as countries for which information concerning total individual consumption expenditure, relative food consumption are incomplete).

Source: ICP 2011, http://www.worldbank.org/en/programs/icp\#5 (access date: 2.08.2017).

The results of the latest ICP edition based on extremely time-consuming process of analysing and processing national statistics for 2011, were made available in 2014 (results of the previous edition which were published in 2008 concerned 2005). ICP 2011 provides the data to 199 countries, including many

\footnotetext{
${ }^{1}$ Cf. http://www.worldbank.org/en/programs/icp\#1.
} 
mini-countries and territories, e.g. individual countries-island of Caribbean and Oceania regions ${ }^{2}$.

One of the aggregates specified in ICP 2011 is "food and non-alcoholic beverages", in short referred to as "food". The shares of the value of consumption of these goods (in retail national prices) in relation the values of total individual consumption expenditure (also expressed in national prices) compared with the volumes of total real consumption (measured on the basis of purchasing power parity for the individual consumption expenditure), illustrate the presence of classical Engel's law (Fig. 1).

The first aim of the article is to present parameters of the (AIDS-type) function of demand for "food". These parameters were estimated by econometric methods (using non-linear method of least squares) on the basis of ICP 2011 data for 41 countries (European countries including, however, almost all non-European OECD member countries). The main objective of the article is to present the estimates on the flexibility rates of demand for "food" (with regard to own price, price of "non-food" aggregate and volume of total consumption). The submitted estimates of the flexibility of demand may be relevant for the long-term assessment of trends in relative prices (of "food" in relation to "non-food"). These estimates suggest that, in a long-term perspective, the trends towards widening the price gaps to the disadvantage of food sector may be expected.

\section{ICP data as a basis for "universal" functions of demand for food}

The Engel's law that was established exactly 160 years ago (often considered as the only universal economic law based rather on empirical observations than "thought experiments"), seems to apply on universal basis (e.g. Houthakker, 1957; Lewbel, 2008). In the context of availability of comparable statistics delivered under international comparison programmes, evolved the concept of econometric estimation of the "universal" functions of consumption demand, including demand for food, obviously taking into account Engel's law. Professor Henri Thiel is regarded as a pioneer of this idea (Theil and Suhm, 1981; Theil and Clements, 1987; Fiebig, Seale and Theil, 1988; Clements and Selvanathan, 1994).

Under Theil's approach (defined as Florida Model ${ }^{3}$ ), the parameters of alleged "universal" (i.e. applicable to grater number of countries covered by the study) functions of consumption demand are estimated. Data concerning struc-

\footnotetext{
${ }^{2}$ Comparative studies on the GDP levels and structures, as well as Purchasing Power Parities of currencies have a long history. Systematic research in this area was initiated in the 1950s by Gilbert and Kravis (Gilbert and Kravis, 1954) and was continued under the auspices of UN, World Bank and OECD, and partially with the participation of organisations and private universities (including Ford Foundation and University of Pennsylvania). ICP was established in 1968. The European Comparison Project (ECP) operates since 1980 and is conducted by Eurostat in cooperation with OECD. ICP integrates ECP data (which has a narrower geographic coverage than ICP) with data for other regions of the world.

${ }^{3}$ From 1981, Henri Theil (1924-2000) was a professor at the State University of Florida in Gainesville.
} 
ture and sizes of consumption volumes and prices for individual countries derives directly from comparative studies. The data set for individual country constitutes a single statistical observation. The data set for all countries constitutes a statistical sample.

In the approaches that estimate the parameters of demand functions for specific countries, there are frequent problems which are not so relevant when we deal with data resulting from comparative studies. It is very difficult to reliably capture the impact of prices on formation of the demand in the standard studies using cross-sectional data (e.g. deriving from the statistics of households' budgets of the specific country in the year concerned). In a given year, all households practically face the same prices. The problem of low volatility of the observed prices arises also when observations are of time series nature (e.g. concerning an average household for a country concerned). In general, changes in price relations are rather slow, even with relatively high inflation. For this reason, estimates of parameters intended to reflect the impact of prices on the level and structure of demand may be of low reliability.

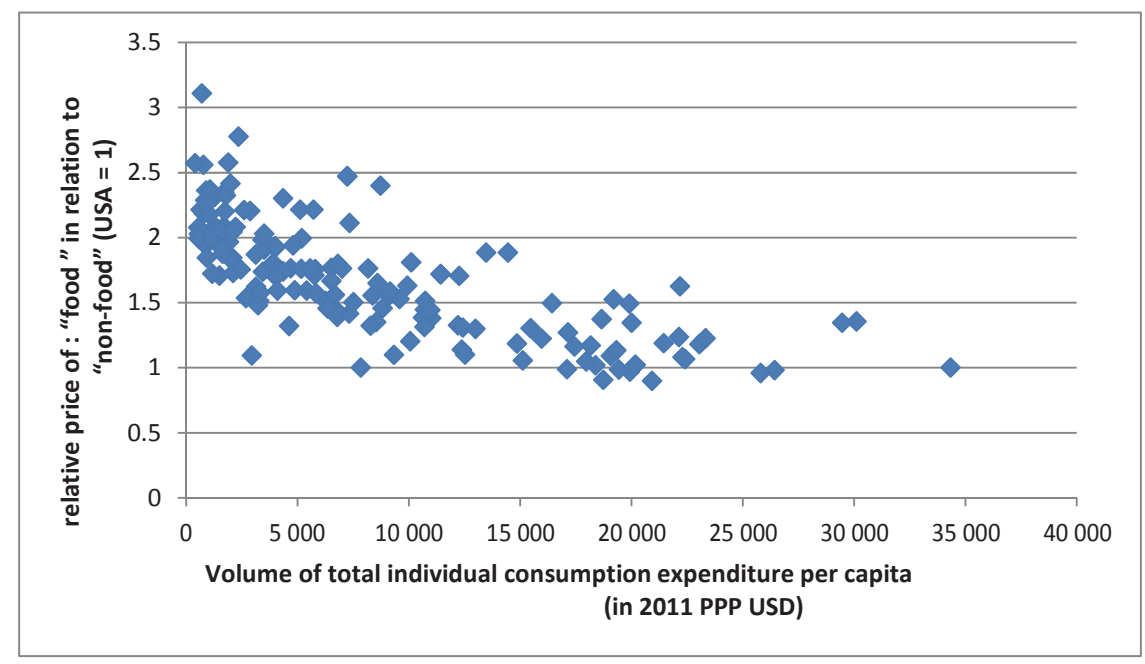

Fig. 2. Relative prices of "food" in relation to other, (non-food) consumer goods and services depending on the volume of total individual consumption expenditure per capita.

Source: as for Fig. 1.

As differentiation of the price structures (i.e. structures of the purchasing power parities) provided by international comparative studies is generally very significant (Fig. 2), it can be expected that statistical reliability of the parameters of demand functions estimated on the basis of data coming from these studies will be greater. 
Fig. 2 documents a large differentiation in relative prices (food/other consumption goods and services) also for countries at similar levels of development (i.e. similar levels of the total individual consumption expenditure per capita). In addition, Fig. 2 shows that with the increase of the volume of total consumption (i.e. with increase in wealth), food becomes relatively cheaper.

Table 1 illustrates the type of data relating to individual consumption realised by households (total consumption) and consumption of foods deriving (or possible to conclude) from ICP 2011 for Mexico, Poland, Switzerland and the USA ${ }^{4}$.

Table 1

ICP 2011 output for Mexico, Poland, Switzerland and the USA

\begin{tabular}{|c|c|c|c|c|c|}
\hline & Specification & Mexico & Poland & Switzerland & USA \\
\hline 1 & $\begin{array}{l}\text { Value of total consumption per capita } \\
\text { (in national currencies and prices) }\end{array}$ & $83,338.2$ & $24,240.5$ & $42,622.7$ & $34,328.7$ \\
\hline 2 & $\begin{array}{l}\text { Volume of total individual consumption } \\
\text { expenditure per capita (in PPP USD) }\end{array}$ & $9,321.8$ & $12,518.8$ & $26,417.6$ & $34,328.7$ \\
\hline 3 & PPP for total consumption & 8.940 & 1.936 & 1.613 & 1.000 \\
\hline 4 & PPP for food & 9.640 & 2.095 & 1.587 & 1.000 \\
\hline 5 & $\begin{array}{l}\text { PPP for non-food consumer goods } \\
\text { and services }\end{array}$ & 8.776 & 1.904 & 1.617 & 1.000 \\
\hline 6 & Volume of food consumption (in PPP USD) & $2,014.1$ & $2,159.1$ & $2,364.0$ & $2,238.1$ \\
\hline 7 & $\begin{array}{l}\text { Volume of consumption of non-food } \\
\text { consumer goods and services (PPP in USD) }\end{array}$ & $7,284.0$ & $10,357.2$ & $24,042.5$ & $32,090.7$ \\
\hline 8 & $\begin{array}{l}\text { Share of the expenditure on food } \\
\text { in relation to the total expenditure }\end{array}$ & 0.233 & 0.187 & 0.088 & 0.065 \\
\hline
\end{tabular}

Note: PPP means purchasing power parity of the national currency against US dollar. PPP for total consumption for Poland (amounting to 1.936, see line 3 in Table 1) means that in Poland (in 2011) it was possible to purchase a basket of goods and services for PLN 1.936 worth 1 dollar in the USA. The purchasing power parities are calculated for different goods and services sub-aggregates. These parities are generally different from the parities for aggregates as different sub-aggregates are valued differently in different countries. ICP 2011 does not provide data for item in line 5 (i.e. purchasing power parity for the aggregate of total non-food ingredients of the consumption) and for item in line 7 (volumes of consumption of other (non-food) goods and services). These items were adjusted upwards by the author ${ }^{5}$. It is worth noting that while food consumption volumes for the countries included in Table 1 (line 6) do not show excessive differentiation, the "non-food" consumption volumes (line 7) differ significantly.

Source: as for Fig. 1.

\footnotetext{
${ }^{4}$ Taking into account USA is motivated by its role as a reference point for all ICP data. Mexico and Switzerland are included as an examples of countries that are different from Poland (in a negative and positive way) in terms of volume of total consumption per capita (line 2 in Table 1).

${ }^{5}$ PPP for the aggregate of other (non-food) consumer goods and services was calculated for each country based on the assumption that PPP for total individual consumption expenditure (line 3 ) is an appropriate mean of parities (PPP) for "food" (line 4) and "non-food" (line 5). This mean is indicated by Fisher's formula (i.e. it is a geometric mean of Paasche and Laspeyers indices for a given country in relation to the USA). The value of PPP for "non-food" is a (positive) solution of the quadratic equation derived from Fisher's formula. Following the designation of PPP for "non-food", calculation of the volume of its consumption (line 7 ) is relatively easy: $(7)=[(1)-(2) \cdot(4)] /(5)$.
} 


\section{Estimates of parameters of the function of demand for AIDS-type food}

In the context of the survey of household budgets, the logarithmic form of dependence of the share of expenditures related to the individual categories of goods on the level of total expenditures was suggested (Working, 1943).

Working's formula has the following form:

$$
s_{j}=a_{j}+b_{j} \cdot \log (Y)
$$

where:

$s_{j} \quad-$ means share of $j$ good in relation to total expenditures,

$Y \quad-$ means total amount of expentiture,

$\log (Y) \quad$ - means natural logarithm of $Y$ value,

$a_{j}$ and $b_{j}$ - estimated parameters.

Demand functions implied by the above formula have the following form:

$$
Q_{j}=Y \cdot s_{j} / p_{j}=Y \cdot\left(a_{j}+b_{j} \cdot \log (Y)\right) / p_{j}
$$

Logarithmic form applied to expenditure on food (and other non-food, consumption expenditures) ensures good match with empirical data - at least as long as the relative prices (of "food" in relation to "non-food") are not significantly diversified.

This observation underpins the specific form of demand function concerning also significant volatility of relative prices.

One of the specific forms modifying Working's form was proposed by Theil and his co-workers. However, this form requires adoption of quite restrictive theoretical assumptions requesting specific structure of consumers' preferences. In addition, it is quite cumbersome in application as it does not provide classical, directly interpreted estimates (in line with Alfred Marshall's definition) of demand flexibility in relation to prices.

Alternative form proposed by Deaton and Muellbauer in 1980 (known as Almost Ideal Demand System - AIDS) is one of the so-called flexible demand systems and it is much more convenient in use and allows us to directly calculate classically understood demand flexibility. As such, it is broadly used in the empirical studies (as well as in studies not using data deriving from international comparative studies).

With two highlighted aggregates of goods and services that constitute total consumption (in this case "food" and "non-food"), AIDS form for the share of 
"food" in total consumption expenditure (s) takes (with certain additional assumptions) the following form ${ }^{6}$ :

$$
s=a+b \cdot\left[\log \left(Y / Y^{\circ}\right)-a \cdot \log \left(P_{f}\right)-(1-a) \cdot \log \left(P_{n}\right)-0.5 \cdot c \cdot\left(\log \left(P_{f} / P_{n}\right)\right)^{2}\right]+c \cdot \log \left(P_{f} / P_{n}\right)
$$

Three parameters are estimated (indicated by symbols $a, b, c) . Y$ is a total amount of expenditure per capita (in national prices); $Y^{\circ}$ is a fixed scale parameter (constituting 34328.7 - total expenditure per capita in "base" country - in this case, the USA); $P_{f}=P P P_{f}$ and $P_{n}=P P P_{n}$ are purchasing power parities of the national value in relation to USD (regarding "food" and "non-food", respectively). It is worth noting that $\left(P_{f} / P_{n}\right)$ is a relative price of "food" in relation to "non-food" (by definition, this price equals to 1.000 for the USA).

A number of empirical studies (based on data for countries with medium and high level of development) suggest that " $b$ " parameter estimated in Theil's previous models ${ }^{7}$ amounts ca. - 0.15 . This fact is documented, for example, in Theil, Chung and Sale works (1989) The estimates of this parameter for data from previous editions of the European Comparison Project (acquired under AIDS model) also vary between -0.14 and -0.16 (Podkaminer, 1999, 2004). The estimates obtained under Working's formula (not including volatility of the relative prices) also oscillate around -0.15 . Implication of this fact includes a practical rule, according to which doubling of the volume of total consumption results (ceteris paribus) in reducing the share of food in total expenditure by ca. 10 percentage points $(-0.15 \log (2) \approx-0.10)$. As a consequence, the share of other (non-food) items of total expenditure increases by 10 percentage points.

It should be noted, that samples of countries taken into account when estimating parameters often include countries that are heterogeneous not only in terms of the level of economic development but also in terms of geography, climate and culture. Combined consideration of countries with extremely different characteristics may be risky, partly because countries with very low level of the economic development may not have a professional statistical system being able to deliver reliable data on the levels and structure of prices and consumption.

As a result of application of non-linear method of the least squares to ICP 2011 data, the estimates of parameters $(a, b, c)$ of AIDS function for the share of "food" in total consumption were obtained. Table 2 shows these estimates

\footnotetext{
${ }^{6}$ Podkaminer (1999). AIDS form distinguishing 3 aggregates of goods and services is formulated and estimated in Podkaminer's works $(1999,2013)$.

${ }^{7}$ In more recent Theil's models, the estimated "b" parameter is closer to the value of -0.10 (e.g. Regmi and Seale, 2010; Meade, Regmi, Seale and Muhammad, 2014). A probable cause of the "inflation" of "b" value is the fact that these studies consider the aggregate covering not only food and non-alkoholic beverages but also tobacco and alcohol products. In addition, these studies include data for countries with extremely different levels of economic and social development.
} 
for two samples: complete sample covering 159 countries and incomplete sample covering 41 countries (including OECD member countries and other European countries) ${ }^{8}$.

Table 2

Estimates of parameters of AIDS function for "food"

\begin{tabular}{lcccc}
\hline \multirow{2}{*}{ Specification } & \multicolumn{3}{c}{ AIDS function parameters } & Adjusted R2 \\
\cline { 2 - 5 } & $\mathrm{a}$ & $\mathrm{b}$ & $\mathrm{c}$ & \\
\hline \multirow{2}{*}{ Complete sample } & 0.0576 & -0.0702 & 0.2667 & \\
(159 countries) & $0.0124^{*}$ & $0.0087^{*}$ & $0.0328^{*}$ & 0.7772 \\
& $0.0000 \#$ & $0.0000 \#$ & $0.0000 \#$ & \\
Incomplete sample & 0.0409 & -0.1407 & 0.0836 & \\
(41 countries) & $0.0083^{*}$ & $0.0125^{*}$ & $0.0296^{*}$ & 0.8772 \\
& $0.0000^{\#}$ & $0.0000^{\#}$ & $0.0075^{\#}$ &
\end{tabular}

Items marked with * represent standard deviations of estimates (from first line of Table 2); items marked with \# determine probability of the estimated parameter being equal to zero.

Source: own calculations based on ICP 2011 data (as for Fig. 1).

The "b" parameter estimated on the basis of the complete sample $(-0.0702)$ differs significantly from the value of -0.15 . However, the values that are close to -0.15 are characterised by patterns observed in countries with medium and high level of development. The parameter $(-0.0702)$ is closer to the value of -0.10 reported in the studies based on ICP 2005 and ICP 1996 data, which take into consideration all surveyed countries (regardless of their level of development).

However, $b=-0.1407$ estimated for the sample not covering African, Asian (except Japan, Israel and Turkey) and Latin American (except Mexico) countries is consistent with the values reported in literature. $90 \%$ confidence interval for this parameter is determined with the values of -0.119 and -0.162 . With the "b" parameter equal to -0.1407 , the expected decrease in the share of the food expenditure by 9.8 percentage points $(-0.098=-0.1407 \cdot \log (2))$ corresponds to duplication of the income level per capita (when the prices remain unchanged). In this case, $90 \%$ confidence interval for decrease in the share of food expenditure is determined with the value of 8.3 and 11.2 (percentage point). However, it should be highlighted that this rule applies in relation to countries with medi-

\footnotetext{
${ }^{8}$ The incomplete sample does not cover Ukraine, Russia, Moldova and Belarus. Due to doubts concerning data for Bulgaria, Montenegro, these countries were also excluded from the incomplete sample. According to ICP, in Bulgaria, the volume of food consumption per capita reaches less than half of the level of neighbouring Greece, which seems unlikely, on the contrary, according do ICP, the volume of food consumption in Montenegro is much higher than, for example, in France and Germany and it is over $70 \%$ higher than in neighbouring Serbia. Probably, in this case, the food consumption also included foreign tourists consumption. In case of the non-EU countries that are OECD members, the data for Chile and South Korea suggesting unbelievably low levels of food consumption were not included.
} 
um and high level of total consumption volume. In the light of the estimation of "b" parameter for the complete sample of countries $(b=-0.0702)$, the estimated decrease in the share of food expenditure in countries with low level of total consumption would have to be lower smaller ( $90 \%$ confidence interval for this parameter is limited by values: -0.056 and -0.085$)$.

Regression function estimated for the complete sample ensures worse adjustment of AIDS function to observations than the regression function estimated for the incomplete sample (the so called adjusted determination rate $\mathrm{R}^{2}$ is much higher for incomplete sample). It is interesting that the regression function estimated for the incomplete sample very closely approximates the actual (i.e. adopted in ICP) amount of the share of food in consumption expenditures for Poland. According to ICP, the share amounts to 0.187 (i.e. 18.7\%), while the share calculated in line with AIDS formula specified by estimates from the bottom of Table 2 amounts to 0.189 . Differences between "theoretical" and actual values are more significant for Hungary and Macedonia and the USA. In the context of the total consumption volume, the USA deviates so much from the level of other (even the wealthiest) countries of the group of 41 countries under consideration that its exclusion from this group could be justified. (An entirely different issue is whether ICP 2011 data does not overestimate the level of total consumption volume for the USA. ${ }^{9}$

The share of food in the expenditure calculated for Poland according to AIDS formula specified by estimates from the top of Table 2 accounts for 0.157 deviating significantly from the actual value.

\section{Food demand flexibility}

Finally, estimated (on the basis of the data for 41 countries) function of "food" demand takes the following form:

$Q_{f}=\left(Y / P_{f}\right) \cdot s=$

$=\left(Y / P_{f}\right) \cdot\left(0,0409-0,1407 \cdot\left[\log \left(Y / Y^{\circ}\right)-0,0409 \cdot \log \left(P_{f}\right)-0,959 \cdot \log \left(P_{n}\right)-0,0418 \cdot\left(\log \left(P_{f} / P_{n}\right)\right)^{2}\right]+\right.$

$\left.+0,0836 \cdot \log \left(P_{f} / P_{n}\right)\right)$

On the other hand, the "non-food" demand is determined in accordance with the following formula:

$$
Q_{n}=\left(Y / P_{n}\right) \cdot(1-s)
$$

\footnotetext{
${ }^{9}$ In particular, one may have doubts about the volume of healthcare services consumption in the USA. The mortality rates for the USA are clearly higher than in many other countries under consideration and the vitality levels are lower (and comparable with the level of rather underprivileged countries such as, for example, Mexico). The actual (including quality factor) level of consumption of the healthcare services in the USA should adequately take into account this fact (which does not seem to be the case).
} 
Estimates of the flexibility of "food" (and non-food) demand depend on estimated parameters and ICP output configurations for particular countries. Therefore, estimates of the flexibility of "food" demand in relation to own price $\left(P_{f}\right)$, "non-food" prices $\left(P_{n}\right)$ and values of total expenditure $(Y)$ are volatile. At the same time, they show certain regularities (Figure 3 ) that are generally consistent with the expectations.

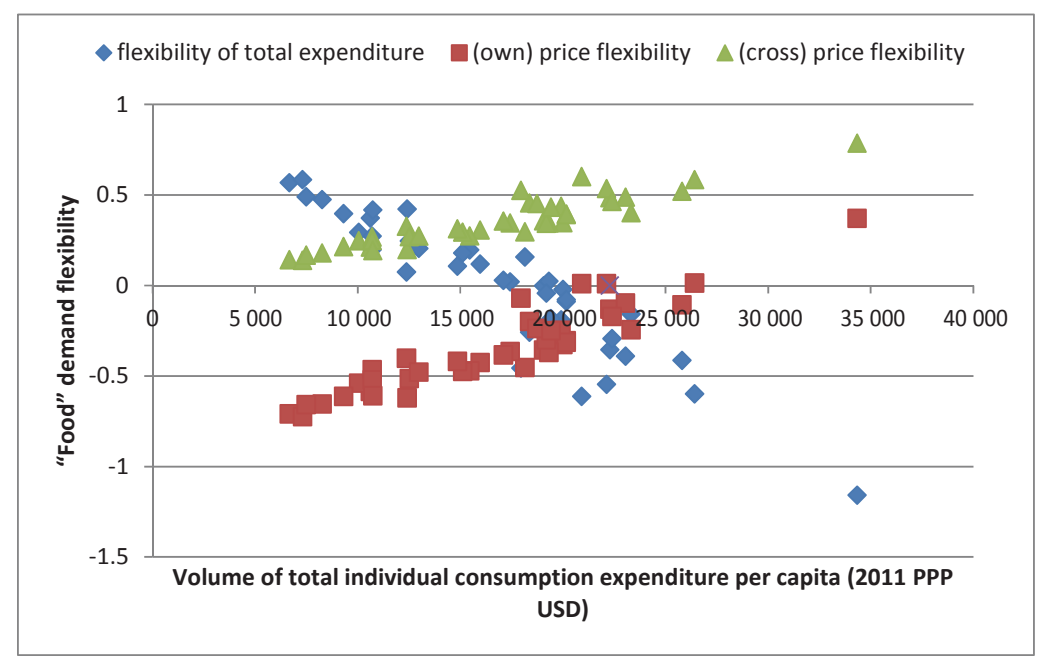

Fig. 3. Flexibilities of food demand in relation to the value of total expenditure, own price and price of "non-food" aggregate, depending on the volume of total consumption.

Source: own calculations based on ICP 2011 data (as for Fig. 1) and estimations of AIDS function parameters from the bottom of Table 2 .

The estimates of the flexibilities of food demand in relation to the value of total expenditure are positive for the countries with relatively low volume of total consumption. However, these flexibilities get lower as the total consumption volume grows. For countries, in which the total consumption volume was higher than ca. PPP USD 17 thousand, these flexibilities are already negative and get lower as total consumption volume evolves. In other words, the food is a "normal good" with relatively low level of the total consumption volume (and thus real income), but also "inferior good" with appropriately high level of total consumption. It is worth noting that "non-food" has a "luxurious good" nature in all 41 countries. The flexibilities of the "non-food" demand in relation to the values of total expenditure vary from 1.91 (for the USA) to 2.30 (for Macedonia) For Poland, this value equals 2.07 , which means that a $1 \%$ increase in the value of total expenditure leads to (ceteris paribus) approximately $2 \%$ increase in the demand for "non-food". 
The estimates of "food" demand flexibility in relation to own price are negative (and higher than -1.00) for vast majority of countries. In other words, "food" demand is "inflexible". The level of "inflexibility" of "food" demand increases with the volume of total consumption. For three countries with a very high total consumption volume (Canada, Great Britain and Switzerland), the flexibilities of "food" demand in relation to own price are practically equal to zero. The estimated flexibility for USA has a positive value, which could suggest that in the USA conditions, "food" becomes "Giffen's good" (i.e. demand for this food react positively to increase in own price). Obviously, this conclusion should be treated caution. As mentioned earlier, AIDS function estimated for 41 countries does not ensure good compliance with the data for the USA. The estimates of the flexibility rates for the USA may, therefore, be burdened with very significant errors. In addition, it seems likely that in the USA conditions, the positive flexibility of "food" demand in relation to own price may be the evidence of the occurrence of the so-called Veblen's effect, rather than Giffen's paradox. A very high level of wealth may lead to purchasing luxurious and "organic" (i.e. particularly expensive) food. It is possible that in the USA conditions, consumption of the expensive food becomes the way to demonstrate social and economic position. More expensive products may win the race with cheaper products as higher prices may be generally identified (rightly or wrongly) with a higher quality (Stiglitz, 1987).

The estimates of cross flexibility, i.e. measurement of the impact of increase in price of "non-food" aggregate on the change in "food" demand, are positive, which is a natural consequence of the fact that as long as only two goods are under consideration, they must be a substitute - according to micro-economic theory. The values of cross flexibilities increase with the total consumption volume (assuming the maximum value for the USA).

For Poland, the estimated flexibility of "food" demand in relation to the value of total consumption expenditure amounts to 0.2459 , whereas the estimated flexibility in relation to own price is negative and amounts to -0.5148 . The estimated cross flexibility amounts to 0.2690 . In other words, one would expect that the $1 \%$ increase in the total expenditure value would increase (ceteris paribus in relation to 2011) the volume of the "food" demand by ca. $0.25 \%$. On the other hand, the $1 \%$ increase in the price of "food" aggregate was to decrease (ceteris paribus) the volume of "food" demand by ca. $0.5 \%$ and the $1 \%$ increase in the price of "non-food" aggregate was to increase the volume of the "food" demand by ca. $0.25 \%$.

A vast majority of the empirical studies referred to in literature, reviews the factors determining the process of development of demand for particular components of the "food" aggregate (distinguishing, for example, meat and meat products, bread, dairy, etc.). Studies may result in flexibility estimates for individual components. However, it is rather difficult to aggregate these estimates so as to obtain the estimates of flexibility for the whole "food" aggregate. There- 
fore, there is no possibility to compare the estimates of flexibilities for the whole "food" aggregate (mentioned above) with the results of other empirical studies. ${ }^{10}$

\section{Impact of the change in the supply volumes in relation to the relative price of food}

Under conditions of the market balance (dominant in market-economy countries), the volumes of demand for different goods are equal to volumes of their supply. The prices not only determine the demand volumes but also, ensure adjustment of demand to supply, all at once. At the same time, the market value of the aggregated supply (corresponding to the market value of the aggregated demand) is equal to the value of the implemented consumption expenditure $(Y)$. On the basis of the above identities, the specific conclusion can be drawn on the impact of the supply volumes change on the relative prices of market balance. In this context, the objective is to estimate the power and direction of the impact of changes in the supply of two aggregates ("food" and "non-food") on the changes in "food" prices in relation to "non-food" prices (i.e. $P_{f} / P_{n}$ ).

Figure 4 shows the estimated flexibilities of relative price $P_{f} / P_{n}$ in relation to the volumes of "food" and "non-food" supply for 41 countries under consideration. It turns out that the flexibilities of the relative price $P_{f} / P_{n}$ in relation to the "food" supply volume are negative for all countries (although they tend to increase as the total consumption volume grows). For Poland, this flexibility is equal to -0.80 . This means that under conditions of 2011, a $1 \%$ increase in the "food" supply would weaken (ceteris paribus) the relative price of "food" by ca. $0.8 \%$.

On the other hand, the flexibilities of relative price $P_{f} / P_{n}$ in relation to the volumes of "non-food" supply show a downward trend. However, they are positive only to the total consumption volume level of ca. PPP USD 17 thausand per capita. Above this level, these flexibilities are negative. For Poland, the estimated value of this flexibility is 0.18 . This means that under conditions of 2011 , a $1 \%$ increase in the "non-food" supply would strengthen (ceteris paribus) the relative price of "food" by ca. $0.18 \%$.

The fact that the flexibilities of the relative price $P_{f} / P_{n}$ in relation to the volumes of "food" supply are negative is not unexpected. However, the fact that the flexibilities of the relative price in relation to the "non-food" supply volume are also negative (for wealthier countries) may be considered as rather unexpected

\footnotetext{
${ }^{10}$ The flexibilities achieved in the Theil-type models for ICP 2005 and ICP 1996 (Meade, Regmi, Seale and Muhammed, 2014; Muhammad, Seale, Meade and Regmi, 2013; Regmi and Seale, 2010; Seale Regmi and Bernstein, 2003) cannot be directly compared with the flexibilities for ICP 2011 presented in Figure 3. Firstly, the flexibilities presented in Figure 3 are calculated in line with the classical Marshall's definition, whereas the flexibilities from the above-mentioned works are defined in different manner. Secondly, in these works, the "food" aggregate also covers tobacco products and alcoholic beverages. Thirdly, the samples taken into account in the estimates reported in the above-mentioned works, include all countries listed in ICP 1996 and ICP 2005 (114 and 144 countries, respectively) - regardless of their level of development. Fourth, these works do not consider one "food" aggregate. There are 8 different "food" sub-aggregates distinguished ("clothes and footwear", "rent and charges", etc.).
} 
conclusion. Nevertheless, this conclusion is correct not only in terms of calculation. As already stated, starting from total consumption volume amounting to ca. PPP USD 17 thausand, "food" becomes "inferior good": demand for it decreases as the total consumption volume grows. When the supply (and thus the consumption volume) of "non-food" reaches appropriately high level with the effect that the total consumption volume exceeds the threshold of PPP USD 17 thausand, "food" becomes "inferior good" - demand for it decreases. In this way, the increase in "non-food" supply does not strengthen the prices of "food" (which is still the case with lower levels of total consumption volume).

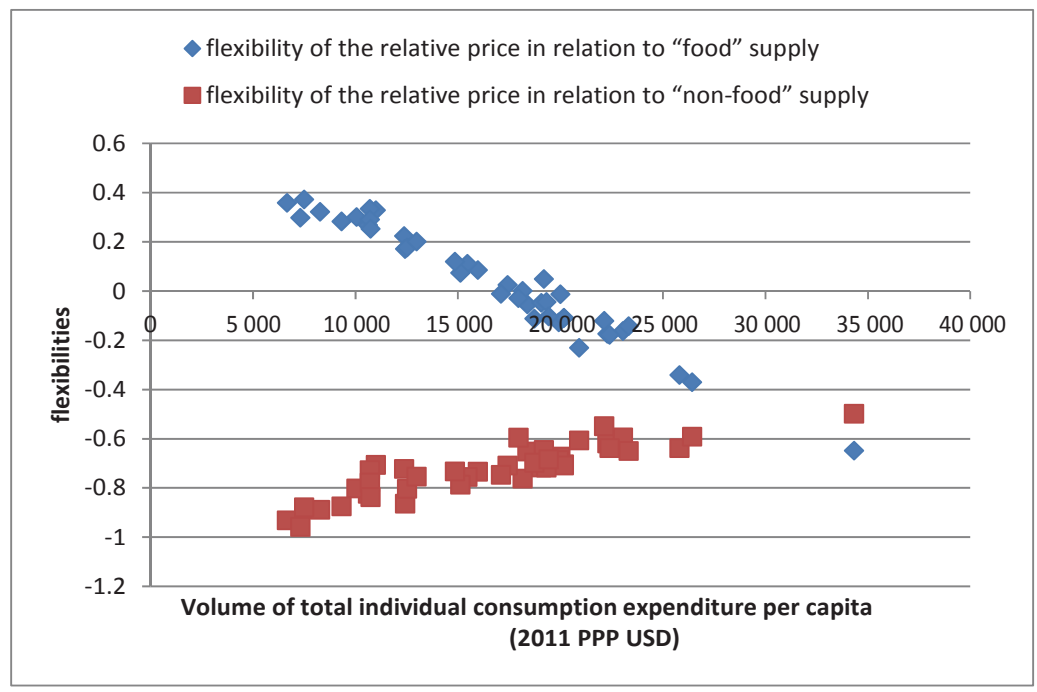

Fig. 4. Flexibilities of the relative price $P_{f} / P_{n}$ in relation to the volume of "non-food" and "food" supply, depending on the volume of total consumption.

Source: own calculations based on ICP 2011 data (as for Fig. 1) and estimations of AIDS function parameters from the bottom of the Table 2 .

In other words, in less wealthy countries (including Poland), the increasing volume of "non-food" supply strengthens (ceteris paribus) the relative price of "food". However, this effect cannot be expected in highly developed countries.

In the highly developed countries, the flexibilities of relative price $P_{f} / P_{n}$ in relation to the volumes of "non-food" and "food" supply are negative. This fact should be linked to the tendency to "widen the price gap affecting the agriculture" (or rather affecting food industry). In wealthier countries, strengthening of the relative price $P_{f} / P_{n}$ would require appropriately large decrease of the "food" supply. Obviously, this postulate is implemented partly under the policy related to reduction of agricultural production and food products supply (including, particularly, agri-food products import) which is applied in nearly all highly developed countries, including in the European Union. 


\section{References}

Clements, K.W., Selvanathan, S. (1994). Understanding consumption patterns. Empirical Economics, vol. 19, no. 1, pp. 69-110.

Deaton, A.S., Muellbauer, J. (1980). An Almost Ideal Demand System. American Economic Review, vol. 70, no. 3, pp. 312-326.

Fiebig, D.G., Seale, J., Theil, H. (1988). Cross-country demand analysis based on three phases of the international comparison project. In: J. Salazar-Carillo, D.S. Prasada Rao (red.), World Comparison of Incomes, Prices and Product. North Holland, Amsterdam, pp. 225-236.

Gilbert, M., Kravis, I.B. (1954). An International Comparison of National Products and Purchasing Power of Currencies. Paris: OECD.

Houthakker, H. (1957). An International Comparison of Household Expenditure Patterns, Commemorating the Century of Engel's Law. Econometrica, vol. 25, no. 4, pp. 523-551.

Lewbel,A.(2008).Engelcurve.In:S.N.Durlauf,L.E.Blume(ed.),TheNewPalgrave Dictionary of Economics Online. Palgrave Macmillan. Retrieved from: http://www.dictionaryofeconomics.com/article?id=pde2008_E000085, DOI:10.1057/9780230226203.0476

Meade, B., Regmi, A., Seale, J.L., Muhammed, A. (2014). New International Evidence on Food Consumption Patterns. U.S. Department of Agriculture Technical Bulletin 1937.

Muhammad, A., Seale, J.L., Meade, B., Regmi, A. (2013). International Evidence on Food Consumption Patterns: An Update Using 2005 International Comparison Program Data. U.S. Department of Agriculture Technical Report 1929 (revised 2013).

Podkaminer, L. (1999). Non-tradable goods and deviations between purchasing power parities and exchange rates: evidence from the 1990 European Comparison Project. In: H. Gabrisch, H., R. Pohl (ed.), EU Enlargement and Its Macroeconomic Effects in Eastern Europe. New York: Macmillan, pp. 62-93.

Podkaminer, L. (2004). Why is food cheaper in rich (European) countries? Banca Nazionale del Lavoro Quarterly Review, vol. 62, no. 230, pp. 297-327.

Podkaminer, L. (2011). Why are goods cheaper in rich countries? Beyond the Balassa-Samuelson Effect. Metroeconomica, vol. 62, no. 4, pp. 712-728.

Podkaminer, L. (2013). Persistent gaps between purchasing power parities and exchange rates under the law of one price: a puzzle (partly) explained? Bank i Kredyt, vol. 44, no. 4, pp. 333-352.

Regmi, A., Seale, J.L. (2010). Cross-Price Elasticities of Demand Across 114 Countries. U.S. Department of Agriculture Technical Report 1925.

Seale, J.L., Regmi, A., Bernstein, J. (2003). International Evidence on Food Consumption Patterns. U.S. Department of Agriculture Technical Report 1904.

Stiglitz, J.E. (1987). The Causes and Consequences of the Dependence of Quality on Price. Journal of Economic Literature, vol. 25, no. 1, pp. 1-48.

Theil, H., Chung, C-F., Seale, J.L. (1989). International evidence on consumption patterns. JAI Press.

Theil, H., Clements, K.W. (1987). Applied Demand Analysis: Results From System-Wide Approaches. Ballinger Publishing Company, Cambridge, Mass.

Theil, H., Suhm, F.E. (1981). International Consumption Comparison: A System-Wide Approach. North Holland, Amsterdam.

Working, H. (1943). Statistical laws of family expenditure. Journal of the American Statistical Association, vol. 38, no. 221, pp. 43-56. 
LEON PODKAMINER

Wyższa Szkoła Finansów i Prawa

Bielsko-Biała

Wiedeński Instytut Międzynarodowych

Porównań Gospodarczych

Wiedeń

\title{
POPYT NA ŻYWNOŚĆ W ŚWIETLE DANYCH MIĘDZYNARODOWEGO PROGRAMU PORÓWNAWCZEGO DLA 2011 ROKU
}

\begin{abstract}
Abstrakt
W oparciu o dane Międzynarodowego Programu Porównawczego dla 2011 r. oszacowano parametry funkcji popytu na dwa agregaty spożycia indywidualnego: żywność oraz pozostałe dobra i ustugi (,nieżywność”). Wyestymowane funkcje popytu typu AIDS zapewniaja dobre dopasowanie do danych dla 41 krajów. Elastyczności popytu na żywność obliczone na podstawie danych wyjściowych oraz oszacowanych parametrów wskazuja, że żywność jest „dobrem normalnym” w krajach o wolumenie spożycia ogółem mniejszym niż ok. 17 tys. „dolarów międzynarodowych” rocznie na osobe. Powyżej tego poziomu żywność jest „,dobrem poślednim” (popyt na nia maleje wraz ze wzrostem wolumenu spożycia ogółem). Własna elastyczność cenowa popytu na żywność jest większa od -1,0, tzn. popyt na żywność jest nieelastyczny. Dodatkowo przedstawiono szacunki elastyczności ceny żywności $w$ relacji do ceny „nieżywności” względem wolumenów podaży tak „żywności”, jak $i$ „nieżywności”. Szacunki te sugeruja, że $w$ krajach zamożniejszych wzrost podaży „nieżywności” obniża relatywna cene żywności, co jest zgodne z tendencja do rozwierania sie „nożyc cen” na niekorzyść gospodarki żywnościowej.
\end{abstract}

Słowa kluczowe: Międzynarodowy Program Porównawczy, prawo Engla, popyt na żywność, elastyczności popytu, system AIDS, nożyce cen.

Accepted for print: 15.12.2017.

Unless stated otherwise all the materials on the website are available under the Creative Commons Attribution 3.0 Poland license. Some rights reserved to the Institute of Agricultural and Food Economics - National Research Institute.

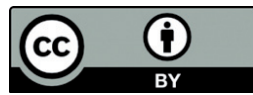

